\title{
PENGARUH PENAMBAHAN KONSENTRASI JUS JAMBU BIJI MERAH (Psidium guajava L.) TERHADAP KADAR ASAM LAKTAT, VITAMIN C, DAN AKSEPTABILITAS SET YOGURT
}

\section{THE EFFECT OF ADDITION OF RED GUAVA (Psidium guajava L.) JUICE CONCENTRATION ON LACTIC ACID LEVELS, VITAMIN C, AND ACCEPTABILITY OF SET YOGURT}

\begin{tabular}{lll}
\hline Received & $:$ Oct $9^{\text {th }}, 2019$ \\
Accepted & $:$ Nov 19 & \\
&
\end{tabular}

Muhamad Raihan Aufa*1, Wendry Setiyadi Putranto ${ }^{2}$, Roostita L Balia ${ }^{2}$

\section{${ }^{1}$ Alumni Fakultas \\ Peternakan, \\ Universitas Padjadjaran. ${ }^{2}$ Departemen Teknologi Hasil Peternakan, Fakultas Peternakan Universitas Padjadjaran.}

*Muhamad Raihan Aufa:

Fakultas Peternakan Universitas Padjadjaran.

Jalan Raya BandungSumedang KM 21 Jatinangor, Sumedang. 45363.

e-mail:

mrai.aufa@gmail.com
Abstract. Red guava has high level of vitamin C, so it can be used as a source of vitamin $C$, also has a distinctive color. This study aims to determine the effect with different concentration of guava juice on lactic acid levels, vitamin $C$ and acceptability of cow milk yogurt set. The experimental method used Completely Randomized Design (CRD) with four treatments increasing the concentration of red guava juice $(0 \%, 5 \%, 10 \%$, and $15 \%)$ and each treatment repeated five times. The results showed that the addition of the concentration of red guava juice by $0 \%$ to $15 \%$, the lactic acid levels of different cow's milk set yogurts showed a negative linear regression pattern with the regression $y=-0,03724 x+1,10465 R^{2}=$ 0,99699 , and increasing vitamin $C$ levels following a positive linear regression pattern $y=1,2932 x-0,324 R^{2}$ $=0,9452$. The concentration of red guava juice $15 \%$ produced the best cow's milk set yogurt with $0,55 \%$ lactic acid levels and 20,69 mg/100 g vitamin C levels produces and produced the most preferred acceptability value with hedonic scale likes and numeric scales 2,20.

Keywords: guava juice concentration, lactic acid, acceptability, vitamin C levels.

\section{Sitasi:}

Aufa, M. R., Putranto, W. S., \& Balia, R. L. (2020). Pengaruh Penambahan Konsentrasi Jus Jambu Biji Merah (Psidium guajava L.) terhadap Kadar Asam Laktat, Vitamin C, dan Akseptabilitas Set Yogurt. Jurnal Teknologi Hasil Peternakan, 1(1):8-16.

\section{PENDAHULUAN}

Susu sapi merupakan salah satu bahan pangan dengan kandungan zat gizi yang baik bagi kesehatan manusia. Namun berdasarkan data, tingkat konsumsi susu dan produk olahannya di Indonesia masih terbilang rendah dibandingkan dengan negara-negara lainnya, yaitu hanya 11,8 liter/kapita/tahun (Agustina, 2016). Hal ini mendorong berbagai industri pangan untuk menyediakan aneka ragam produk olahan pangan susu dengan macam varian bentuk maupun rasa yang diminati oleh masyarakat.

Salah satu bentuk olahan pangan dari susu yang umum di 
masyarakat adalah yogurt. Yogurt merupakan salah satu bentuk produk olahan susu dari hasil fermentasi menggunakan starter bakteri asam laktat. Berdasarkan metode pembuatan dan struktur fisik koagulumnya, yogurt dibagi menjadi dua kategori yaitu, set yogurt dan stirred yogurt. Berbeda dengan stirred yogurt, pada proses pembuatan set yogurt, tahapan inokulasi starter atau fermentasi susu dilakukan di dalam kemasan siap saji dan karakteristik koagulumnya tidak berubah. Biakan bakteri starter dalam proses pembuatan yogurt memegang peranan penting terhadap produk akhir yang akan dihasilkan.

Salah satu cara untuk meningkatkan nilai manfaat produk set yogurt, pada penelitian ini ditambahkan bakteri probiotik yang memiliki efek manfaat kesehatan khususnya dalam saluran pencernaan manusia yaitu Lactobacillus acidophilus. Bakteri ini memiliki keistimewaan memproduksi zat anti mikroba yang akan menstimulasi kekebalan tubuh serta mampu menurunkan kadar kolesterol dalam darah (Lourens-Hattingh \& Viljoen, 2001). Bakteri Streptococcus thermophilus, Lactobacillus bulgaricus dan Lactobacillus acidophilus sebagai starter akan hidup dan saling berstimulasi satu sama lainnya sehingga pertumbuhan bakteri starter akan lebih cepat dalam proses fermentasi. Selama proses fermentasi, bakteri starter akan merombak laktosa pada susu menjadi asam laktat, asamasam organik, dan juga membentuk komponen rasa yang akan menurunkan $\mathrm{pH}$ sehingga produk menjadi kental hingga padat, serta memiliki bau dan rasa yogurt yang khas.

Upaya dalam meningkatkan minat masyarakat terhadap produk set yogurt, yaitu dengan melakukan modifikasi rasa dan tampilan warna dengan pemberian bahan tambahan lain. Salah satu bahan alami yang dapat digunakan adalah jus dari buah jambu biji merah (Psidium guajava L.), karena memiliki cita rasa khas yang diminati konsumen. Selain cita rasa, tingginya kandungan pigmen likopen pada daging buah jambu biji, mampu memberikan warna merah alami dan diharapkan dapat meningkatkan nilai kesukaan atau akseptabilitas masyarakat terhadap produk set yogurt.

Keunggulan lain dalam jus jambu biji adalah tingginya kandungan vitamin $C$ yang merupakan antioksidan alami yang banyak terdapat pada daging buah jambu biji merah yang sudah matang. Antioksidan merupakan senyawa yang dapat melindungi tubuh dari berbagai penyakit terkait keberadaan radikal bebas apabila rutin dikonsumsi.

Selain kandungan nutrisi, tingkat penerimaan konsumen menjadi aspek yang sangat penting. Faktor-faktor terkait dalam penerimaan konsumen yaitu penampakan, bau, warna dan rasa. Produk set yogurt dengan penambahan jus jambu biji merah diharapkan memiliki penampakan yang kental hingga padat, bau khas yogurt, warna merah muda yang menarik bagi konsumen, serta rasa asam khas yogurt dan rasa manis dari jambu biji merah. Hingga saat ini, masih belum banyak produk set yogurt dengan penggunaan pewarna dan perisa alami yang murni terbuat dari jus buah. Minimnya pengetahuan masyarakat akan manfaat keunggulan produk olahan set yogurt dengan penambahan jus jambu biji merah, menjadi dasar pemikiran yang menarik bagi penulis. Oleh karena itu, berdasarkan uraian di atas peneliti tertarik untuk meneliti lebih lanjut mengenai penambahan jus jambu biji merah (Psidium guajava L.) terhadap kadar asam laktat, kadar 
vitamin C, dan akseptabilitas set yogurt susu sapi.

\section{MATERI DAN METODE}

Penelitian ini dilaksanakan melalui dua tahapan, yaitu 1) Persiapan Jus Jambu Biji Merah, dan 2) Pembuatan Set Yogurt dengan Penambahan Jus Jambu Biji Merah.

a. Persiapan Jus Jambu Biji Merah (Modifikasi Chairunnisa, 2011).

Persiapan jus jambu biji merah di awali dengan sortasi buah yang sudah matang. Jambu biji dibersihkan kemudian dikupas dan diiris untuk memperkecil ukuran. Kemudian diekstraksi menggunakan juice extractor dan disaring. Jus jambu biji merah kemudian dipanaskan hingga mencapai suhu $70^{\circ} \mathrm{C}$ selama 15 menit dan dinginkan hingga suhu $42^{\circ} \mathrm{C}$ dengan bantuan air mengalir.

b. Pembuatan Set Yogurt dengan Penambahan Jus Jambu Biji Merah (Modifikasi Lyo-San Inc, 2015; Patil et al., 2009).

Pembuatan set yogurt diawali dengan melarutkan $10 \%$ susu skim bubuk (b/v), 0,7 \% CMC (b/v) dan $7 \%$ gula pasir $(\mathrm{b} / \mathrm{v})$ ke dalam susu sapi segar untuk mencapai bahan kering 20\% (Chairunniasa et al., 2017). Kemudian dipanaskan pada suhu $90-95^{\circ} \mathrm{C}$ selama 30 menit, dan dinginkan sampai suhu $42^{\circ} \mathrm{C}$. Tambahkan bulk culture 5\% (v/v) serta jus jambu biji merah sesuai dengan perlakuan yaitu, (tanpa penggunaan jus jambu), $(5 \%),(10 \%)$ dan $(15 \%)(b / v)$.

Unit percobaan untuk uji kadar asam laktat dan vitamin C menggunakan $100 \mathrm{ml}$ susu sapi dan untuk uji akseptabilitas menggunakan $60 \mathrm{ml}$. Selanjutnya, setiap unit percobaan ditutup rapat mengguna- kan plastik keda udara dan diinkubasi pada suhu $42^{\circ} \mathrm{C}$ selama 6 jam (sesuai hasil penelitian pendahuluan), hingga terbentuk gumpalan sempurna tanpa sineresis. Set yogurt jambu biji merah yang terbentuk kemudian dilakukan analisis kadar asam laktat dan kadar vitamin C, dan sebagian disimpan dalam refrigerator dengan suhu $4^{\circ} \mathrm{C}$ selama 12 jam untuk pengujian akseptabilitas.

c. Rancangan Percobaan.

Penelitian ini dilakukan dengan menggunakan Rancangan Acak Lengkap (RAL) yang terdiri dari empat perlakuan penambahan persentase jus buah jambu biji merah yang berbeda (P0, P1, P2 dan P3) dan masing-masing perlakuan diulang sebanyak lima kali dilanjutkan dengan menggunakan uji Tukey taraf $0,05 \%$. Akseptabilitas diuji dengan uji Kruskal-Wallis, apabila menunjukkan hasil yang berbeda maka dilakukan uji Mann-Whitney untuk menguji perbedaan rata-rata antar perlakuan. Peubah yang diamati meliputi; 1) Kadar Asam Laktat (BSNI, 2009); 2) Kadar Vitamin C (Khasanah et al., 2015); 3) Uji Akseptabilitas (Setyaningsih et al., 2010).

\section{HASIL DAN PEMBAHASAN}

a. Kadar Asam Laktat.

Berdasarkan data pada Tabel 1, semakin tinggi penambahan konsentrasi jus jambu biji merah, maka kadar asam laktat semakin rendah. Kadar asam laktat berdasarkan uji Tukey taraf 0,05\% menghasilkan nilai yang berpengaruh nyata berturutturut terhadap semua perlakuan.

Hasil sidik ragam Polynomial Orthogonal menunjukkan bahwa pengaruh penambahan seluruh perlakuan konsentrasi jus jambu biji merah terhadap kadar asam laktat berbeda nyata $(\mathrm{P}<0,05)$, dengan mengikuti pola persamaan regresi linier 
negatif. Penambahan jus jambu biji merah sebesar 5\%, 10\% dan $15 \%$ nyata menurunkan kadar asam laktat set yogurt susu sapi. Kadar asam laktat set yogurt susu sapi memiliki pola garis linier dengan persamaan $\mathrm{y}=-$ $0,03724 x+1,10465\left(R^{2}=0,99699\right)$.

Koefisien determinasi $\left(\mathrm{R}^{2}\right)$ sebesar 0,99699 menunjukkan bahwa penambahan konsentrasi jus jambu biji merah dalam mempengaruhi kadar asam laktat pada set yogurt susu sapi sebesar 99\%. Hal ini menyatakan konsentrasi penambahan konsentrasi jus jambu biji merah $0 \%$ hingga $15 \%$ berpengaruh nyata terhadap kadar asam laktat. Menurut Syarat Mutu Yogurt SNI 2981:2009, kadar asam laktat yogurt cenderung normal yaitu dalam kisaran 0,5-2,0\%.

Penurunan nilai rata-rata kadar asam laktat pada grafik di atas dikarenakan semakin tinggi konsentrasi penambahan jus jambu biji merah menyababkan karbon (gula) yang tersedia dalam media pertumbuhan menjadi tinggi, selain itu pada pembuatan set yogurt susu sapi ini ditambahkan gula sebesar 7\% untuk memberikan kesan manis sehingga, menyebabkan fermentasi menjadi terhambat. Yusmarini \& Effendi (2004), menyatakan penambahan beberapa jenis karbohidrat dalam pembuatan yogurt yaitu laktosa, sukrosa dan glukosa sebagai sumber karbon, memberikan pengaruh terhadap $\mathrm{pH}$, kandungan asam laktat dan kandu- ngan protein. Lebih lanjut, menurut Gianti \& Evanuarini (2011), semakin tinggi kadar gula pada susu fermentasi cenderung dapat mempengaruhi $\mathrm{pH}$ dan menyebabkan penurunan aktivitas starter. Hal ini dikarenakan konsentrasi medium yang pekat menyebabkan mikroorganisme mengalami osmosis dan pertumbuhannya terhambat, sehingga pembentukan asam laktat semakin menurun. Selain itu, gula yang ditambahkan ke dalam bahan pangan dengan konsentrasi tinggi menyebabkan sebagian besar air berkurang sehingga tidak cukup untuk memenuhi kebutuhan air untuk mikroorganisme (Abdul et al., 2018). Pernyataan tersebut diperkuat oleh Rahman et al. (1992), bahwa pada konsentrasi gula lebih dari 5,5\% maka aktivitas kultur akan mengalami penghambatan.

b. Kadar Vitamin C.

Tabel 1. menunjukkan bahwa semakin tinggi penambahan konsentrasi jus jambu biji merah, maka kadar vitamin $\mathrm{C}$ semakin tinggi. Kadar vitamin $C$ berdasarkan uji Tukey taraf $0,05 \%$. Penambahan konsentrasi jus jambu biji merah 5\% (P1) dengan $10 \%$ (P2) nyata tidak berbeda, namun nyata berbeda dengan perlakuan $0 \%$ (P0) dan 15\% (P3). Penambahan konsentrasi 15\% (P3) nyata lebih tinggi dibandingkan 10\% (P2), $5 \%(\mathrm{P} 1)$, dan $0 \%(\mathrm{P} 0)$

Tabel 1. Total Asam Laktat dan Totall Vitamin C dengan Berbagai Perlakuan

\begin{tabular}{lcccc}
\hline \multirow{2}{*}{ Peubah } & \multicolumn{4}{c}{ Perlakuan } \\
\cline { 2 - 5 } & P0 & P1 & P2 & P3 \\
\hline Kadar Asam Laktat $(\%)$ & $1,10^{\mathrm{a}}$ & $0,94^{\mathrm{b}}$ & $0,72^{\mathrm{c}}$ & $0,55^{\mathrm{d}}$ \\
Vitamin C $(\%)$ & $0,00^{\mathrm{a}}$ & $7,11^{\mathrm{b}}$ & $9,70^{\mathrm{b}}$ & $20,69^{\mathrm{c}}$ \\
\hline
\end{tabular}

Keterangan: Huruf yang berbeda ke arah baris pada kolom yang sama menunjukkan berbeda nyata. 


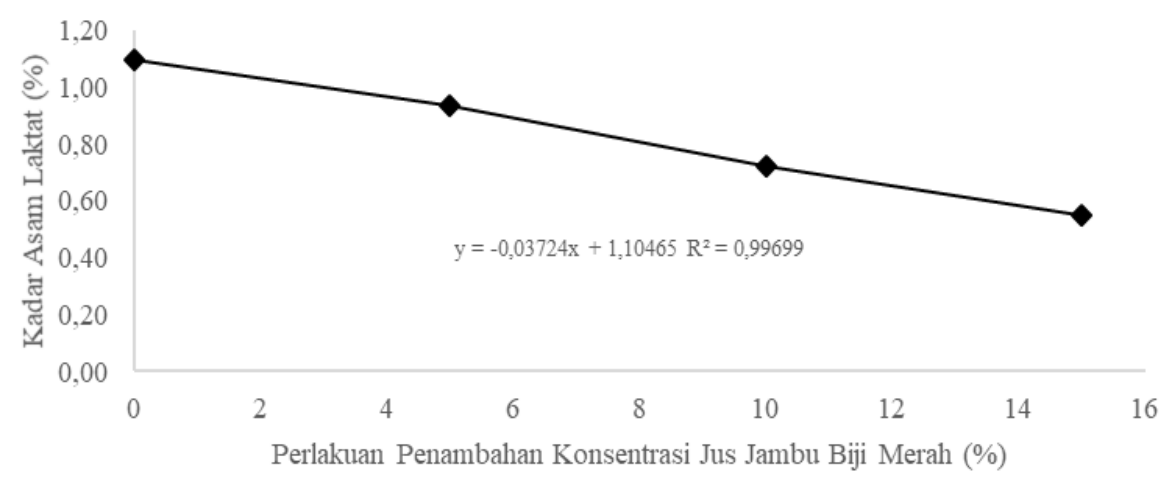

Gambar 1. Grafik Polynomial Orthogonal Pengaruh Penambahan Jus Jambu Biji Merah terhadap Kadar Asam Laktat Set Yogurt Susu Sapi.

Hasil sidik ragam Polynomial Orthogonal menunjukkan bahwa pengaruh penambahan konsentrasi jus jambu biji merah konsentrasi $0 \%$ (P0), 5\% (P1), 10\% (P2), dan 15\% (P3) kadar vitamin $\mathrm{C}$ berbeda nyata $(\mathrm{P}<0,05)$ dengan mengikuti pola persamaan regresi linier positif. Hal ini menunjukkan bahwa penambahan konsentrasi jus jambu biji merah sebesar 5\%, 10\%, dan $15 \%$ nyata meningkatkan kadar vitamin $\mathrm{C}$ set yogurt susu sapi. Kadar vitamin $C$ set yogurt susu sapi memiliki pola garis linier dengan persamaan $y=1,2932 x$ $-0,324\left(R^{2}=0,9452\right)$.

Nilai koefisien determinasi $\left(\mathrm{R}^{2}\right)$ sebesar 0,9452 menunjukkan bahwa penambahan konsentrasi jus jambu biji merah dalam mempengaruhi kadar vitamin $C$ pada set yogurt susu sapi sebesar 96\%. Hal ini menunjukkan konsentrasi penambahan konsentrasi jus jambu biji merah $0 \%$ hingga $15 \%$ berpengaruh nyata terhadap kadar vitamin C.

Penambahan konsentrasi jus jambu biji merah 0\% (P0) tidak terdeteksi adanya kandungan vitamin C (0,00 mg/100g) walaupun menurut Direktorat Gizi Departemen Kesehatan RI (2018), susu sapi segar mengandung kadar vitamin $\mathrm{C}$ sebesar $1 \mathrm{mg} / 100 \mathrm{~g}$, diperkirakan karena susu sapi segar selama pasteurisasi, kandungan vitamin $\mathrm{C}$ rusak akibat pemanasan. Menurut Sofro (1992), vitamin C sangat stabil pada pH 4-6 dan vitamin C mudah teroksidasi di udara, serta sensitif dan mudah rusak terhadap panas. Agar vitamin $C$ tidak mudah rusak dan tetap bersifat stabil maka perlu penyimpanan dalam suhu dingin.

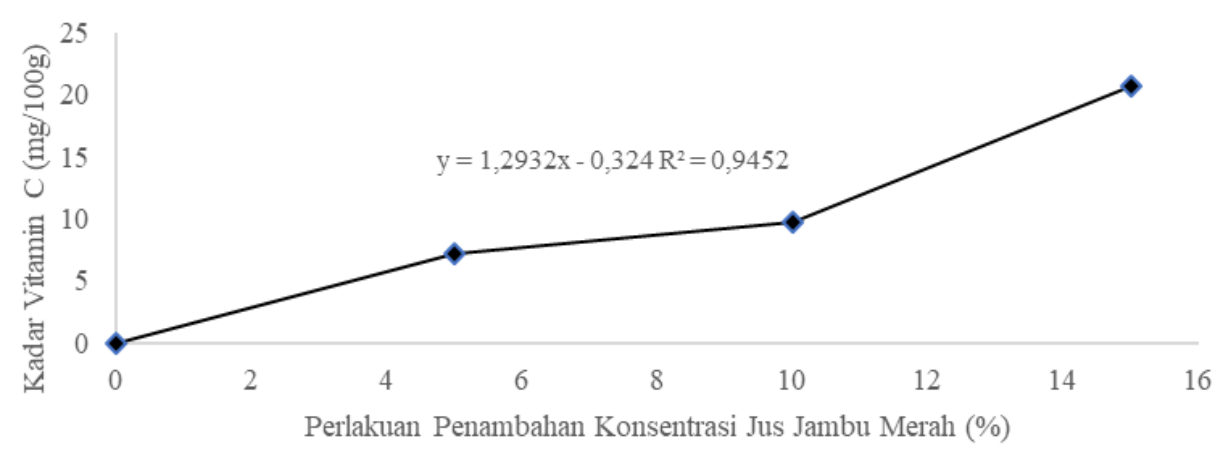

Gambar 2. Grafik Polynomial Orthogonal Pengaruh Penambahan Jus Jambu Biji Merah terhadap Kadar Vitamin C Set Yogurt Susu Sapi. 
Jambu biji memiliki kadar vitamin C yang tinggi yaitu $86 \mathrm{mg} / 100 \mathrm{~g}$ (Rukmana \& Rahmat, 1996). Peningkatan kadar vitamin C pada Gambar 2. disebabkan karena konsentrasi penambahan jus jambu biji merah maka kandungan vitamin $C$ semakin tinggi. Selain itu, pada pembuatan set yogurt susu sapi ini dilakukan proses penyimpanan dingin sehingga dapat mencegah terjadinya kerusakan vitamin $\mathrm{C}$, yang merupakan salah satu zat antioksidan (Padang \& Rasnita, 2017).

\section{c. Aroma Set Yogurt Susu Sapi.}

Tabel 2. menunjukkan bahwa semakin tinggi penambahan konsentrasi jus jambu biji merah, nyata meningkatkan nilai kesukaan berdasarkan aroma set yogurt susu sapi. Nilai rata-rata tertinggi berdasarkan skala numerik adalah pada perlakuan penambahan konsentrasi jus jambu merah biji 15\% (P3) yaitu 2,40 (sukaagak suka). Hal ini disebabkan semakin tinggi konsentrasi jus jambu biji merah semakin tercium aroma jambu dan mempengaruhi kesukaan terhadap aroma set yogurt. Tanggapan terhadap sifat sensori bau atau aroma biasanya diasosiasikan dengan aroma produk atau senyawa tertentu yang sudah umum dikenal dan penciuman bau atau aroma dapat dilakukan secara langsung (Setyaningsih et al., 2010).

\section{d. Rasa Set Yogurt Susu Sapi.}

Tabel 2. menunjukkan bahwa semakin tinggi penambahan konsentrasi jus jambu biji merah, nyata meningkatkan nilai kesukaan berdasarkan rasa set yogurt susu sapi. Nilai rata-rata tertinggi berdasarkan skala numerik adalah pada perlakuan penambahan konsentrasi jus jambu merah biji tertinggi yaitu 15\% (P3) 2,24 (suka-agak suka). Perlakuan penambahan konsentrasi jus jambu biji merah 15\% (P3) sangat disukai oleh panelis dibandingkan dengan perlakuan lainnya karena dipengaruhi oleh rasa manis yang dihasilkan. Menurut Azizah, et al. (2013), penambahan ekstrak buah nangka berdampak pada jumlah gula yang ditambahkan dalam yogurt drink sehingga menimbulkan dampak cita rasa manis yang semakin kuat. Kandungan gula mempengaruhi penilaian panelis terhadap citarasa. Rasa gula yang manis memiliki efek yang besar pada penilaian konsumen terhadap citarasa yogurt (Drake et al., 2001).

\section{e. Warna Set Yogurt Susu Sapi}

Tabel 2. menunjukkan bahwa penambahan konsentrasi jus jambu biji merah nyata berpengaruh meningkatkan nilai kesukaan berdasarkan warna set yogurt susu sapi yang dihasilkan.

Tabel 2. Nilai Akseptabilitas Berbagai Perlakuan

\begin{tabular}{lcccc}
\hline \multirow{2}{*}{ Peubah } & \multicolumn{4}{c}{ Rata-rata Berbagai Perlakuan } \\
\cline { 2 - 5 } & P0 & P1 & P2 & P3 \\
\hline Aroma & $3,32^{\mathrm{a}}$ & $3,08^{\mathrm{ab}}$ & $2,80^{\mathrm{b}}$ & $2,40^{\mathrm{c}}$ \\
Rasa & $4,16^{\mathrm{a}}$ & $3,88^{\mathrm{a}}$ & $2,84^{\mathrm{b}}$ & $2,24^{\mathrm{c}}$ \\
Warna & $3,48^{\mathrm{a}}$ & $3,60^{\mathrm{a}}$ & $3,20^{\mathrm{ab}}$ & $2,40^{\mathrm{b}}$ \\
Penampakan & $3,40^{\mathrm{a}}$ & $3,68^{\mathrm{a}}$ & $2,84^{\mathrm{b}}$ & $2,44^{\mathrm{c}}$ \\
Total Penerimaan & $3,24^{\mathrm{a}}$ & $3,36^{\mathrm{a}}$ & $2,60^{\mathrm{b}}$ & $2,20^{\mathrm{c}}$ \\
\hline
\end{tabular}

Keterangan: Huruf yang berbeda ke arah baris pada kolom yang sama menunjukkan berbeda nyata. 
Nilai rata-rata penerimaan panelis berdasarkan skala numerik adalah pada perlakuan penambahan konsentrasi jus jambu merah biji 15\% (P3) yaitu 2,40 (suka-agak suka) dan seiring menurunnya penambahan konsentrasi jus jambu biji merah akan mengurangi tingkat kesukaan panelis. Warna merupakan parameter pertama yang menentukan tingkat penerimaan konsumen terhadap suatu produk, walaupun warna kurang berhubungan dengan nilai gizi, namun faktor warna tampil lebih dahulu dan tidak jarang sangat menentukan kesukaan (Netty \& Methatias, 2015).

Perlakuan penambahan konsentrasi jus jambu biji merah 15\% (P3) memberikan warna yang disukai yaitu merah khas jambu biji. Menurut Soewarno (1990), diantara sifat-sifat produk pangan yang paling menarik perhatian pada konsumen dan paling cepat pula memberikan kesan disukai atau tidak adalah sifat warna. Menurut Jimenez, et al. (2001) dan Yan, et al. (2006), khusus jambu biji merah mengandung beta karoten yang membuat warna merah dari jambu semakin jelas.

\section{f. Penampakan Set Yogurt Susu Sapi}

Tabel 2. menunjukkan bahwa semakin tinggi penambahan konsentrasi jus jambu biji merah, nyata meningkatkan nilai kesukaan berdasarkan penampakan set yogurt susu sapi. Perlakuan penambahan konsentrasi jus jambu merah biji 15\% (P3) yaitu 2,44 (suka-agak suka) selanjutnya menurun dengan berkurangnya konsentrasi berturut-turut. Hal yang berpengaruh terhadap penampakan yogurt adalah kadar bahan kering bahan baku. Kadar bahan kering jambu biji merah pada penelitian ini sebesar $13,01 \%$ dan berperan penting dalam pembentukan penampakan set yogurt yang padat. Menurut Jimenez et al. (2001) dan Yan et al. (2006), jambu biji merah mengandung bahan kering 13-26\%.
Oleh karena itu, semakin tinggi penamba-han konsentrasi jus jambu biji merah maka penampakan set yogurt akan semakin padat. Hal ini sesuai dengan pernya-taan Chairunnisa (2007), hal lain yang berpengaruh terhadap penampakan yogurt adalah kadar bahan kering bahan baku, yang berperanan penting dalam pembentukan penampakan set yogurt yang padat.

\section{g. Total Penerimaan Set Yogurt Susu Sapi}

Tabel 2. menunjukkan bahwa penambahan konsentrasi jus jambu biji merah mempengaruhi total penerimaan set yogurt susu sapi yang dihasilkan. Nilai rata-rata tertinggi berdasarkan skala numerik adalah pada perlakuan penambahan konsentrasi jus jambu merah biji 15\% (P3) yaitu 2,20 (suka-agak suka) selanjutnya menurun dengan berkurangnya konsentrasi penambahan. Total penerimaan merupakan penilaian terhadap semua set yogurt yang meliputi aroma, rasa, warna, dan penampakan secara subjektif dari produk yang dihasilkan dimana bertujuan untuk mengetahui tingkat penerimaan panelis. Perlakuan penambahan jus jambu biji merah $15 \%$ (P3), menghasilkan nilai skala numerik yang paling disukai karena memiliki aroma yang tidak terlalu berbau susu serta lebih tercium aroma khas jambu. Rasa yang paling manis dibandingkan dengan perlakuan lain, warna lebih sesuai (mendekati merah jus jambu), serta penampakan lebih padat.

\section{KESIMPULAN}

Penambahan konsentrasi jus jambu biji merah sebanyak $15 \%$ (Psidium guajava L.) memberikan pengaruh nyata menurunkan kadar asam laktat $(0,55 \%)$, dan meningkatkan kadar vitamin C (20,69 mg/100g), serta nilai akseptabilitas set yogurt susu sapi yang paling disukai $(2,20)$. 
DAFTAR PUSTAKA

Abdul, A., S. Kumaji, \& F. Duengo. (2018). Pengaruh Penambahan Susu Sapi Terhadap Kadar Asam Laktat Pada Pembuatan Yoghurt Jagung Manis oleh Streptococcus Thermophillus dan Lactobacillus Bulgaricus. Bioma: Jurnal Biologi, 3(2):1-9.

Agustina, T. (2016). Outlook Komoditas Pertanian Subsektor Peternakan Susu. Pusat Data dan Sistem Informasi Pertanian Sekertariat Jenderal Kementrian Pertanian.

Azizah, N., Pramono, Y. B., \& Abduh, S. B. M. (2013). Sifat Fisik, Organoleptik, dan Kesukaan Yogurt Drink dengan Penambahan Ekstrak Buah Nangka. Jurnal Aplikasi Teknologi Pangan, 2(3):148155.

Badan Standarisasi Nasional. (2009). Yoghurt (SNI 2981:2009). Jakarta: Badan Standarisasi Nasional.

Direktorat Gizi Departemen Kesehatan RI. (2018). Daftar Komposisi Bahan Makanan. http: / www.pangan ku.org/id-ID/view

Drake, M. A., Gerard, P. D., \& Chen, Q. (2001). Effects of Sweetener, Sweetener Concentration, and Fruit Flavor on Sensory Properties of Soy Fortified Yogurt. Journal of Sensory Studies, 16(4): 393-405.

Gianti, I. \& Evanuarini, H. (2011). Pengaruh Penambahan Gula dan Lama Penyimpanan Terhadap Kualitas Fisik Susu Fermentasi. Jurnal Ilmu dan Teknologi Hasil Ternak, 6(1):26-33.

Chairunnisa, H. (2007). The Chemical Characteristic and Acceptability of Set Yogurt Made from Caprine-
Milk as Fermented Health Drink. Seminar Nasional PATPI Bandung 2007. Fakultas Peternakan Universitas Padjajaran, Sumedang. 522.

Chairunnisa, H. (2011). Pemilihan Proses Pembuatan Sari Buah Jambu Biji (Psidium guajava L.) untuk Meningkatkan Ketahanan Waktu Saji. Widyatama, 20(2): 123-130.

Chairunnisa, H., Balia, R. L., Pratama, A., \& Dadan, H. R. (2017). Karakteristik Kimia Set Yoghurt dengan Bahan Baku Susu Tepung dengan Penambahan Jus Bit (Beta Vulgaris L.). Jurnal Ilmu Ternak, 17(1):35-39.

Jimenez-Escrig, A., Rincom, M., Pulido, R., \& Saura-Calixto, F. (2001). Guava Fruit (Psidium Guajava L.) as a New Source of Antioxidant Dietary Fiber. J. Agr. Food Chem, 49:5489-5493.

Khasanah, R. N., Tjahjadi, P. \& Ari, S. (2015). Vitamin C Content in Yogurt with the Addition of Tawangmangu Tangerine Juice (Citrus nobilis var. Tawangmangu). Nusantara Bioscience, 7(2):149-152.

Lourens-Hattingh, A., \& Viljoen, B. C. (2001). Yoghurt as Probiotic Carrier Food. International Dairy Journal, 11: 1-17

Lyo-San Inc. (2015). Step-by-Step How to Make Your Own Yoghurt. http: / / www.yogourmet.com

Netty, H., \& Methatias, B. C. (2015). Kajian Variasi Konsentrasi Sukrosa terhadap Karakteristik Nata Timun Suri (Cucumis Sativus L.). Jurnal AGRITEPA., 2(1):89-104. 
Padang, S. A., \& Rasnita, M. M. (2017). Penetapan Kadar Vitamin C pada Buah Jambu Biji Merah (Psidium guajava L.) dengan Metode Titrasi NA-2,6 Dicholorophenol Indophenol (DCIP). Media Farmasi, 13(2).

Patil, A. P., Chavan, K. D., \& Bhosale, D. N. (2009). Influence of Addition of Guava Pulp and Sugar on Sensory Quality of Guava Yoghurt. J. Dairying, Foods E H.S, 28(2):95-100.

Rahman, A. S., Fardiaz, W., Rahayu, P., Suliantari, \& Nurwitri, C. C. (1992). Teknologi Pengolahan Susu. Depdikbud Dirjen PT Pusat Antar Universitas Pangan dan Gizi IPB: Bogor.

Rukmana \& Rahmat. (1996). Jambu Biji. Kanisius: Yogyakarta.
Setyaningsih, D., Apriyantono, A., \& Sari, M. P. (2010). Analisis Sensori untuk Industri Pangan dan Agro. IPB Press: Bogor. 180.

Soewarno, S. (1990). Dasar-dasar pengawasan dan standarisasi mutu pangan. IPB Press: Bogor.

Sofro, A. S. (1992). Protein Vitamin dan Bahan Ikatan Pangan. Gajah Mada University Press: Yogyakarta.

Yan, L. Y., Ten, L. T., \& Jhi, T. J. (2006). Antioxidant Properties of Guava Fruit: Comparison with Some Fruit. J. Sunway Academic, 3:9-20.

Yusmarini \& Efendi, R. (2004). Evaluasi Mutu Soygurt yang dibuat dengan Penambahan Beberapa Jenis Gula. Jurnal Natur Indonesia, 6:104-110. 